\title{
Jung and Deleuze: Enchanted Openings to the Other: A Philosophical Contribution
}

\author{
Christian McMillan
}

Department of Psychosocial and Psychoanalytic Studies, The University of Essex, Colchester, UK

\begin{abstract}
This paper draws from resources in the work of Deleuze to critically examine the notion of organicism and holistic relations that appear in historical forerunners that Jung identifies in his work on synchronicity. I interpret evidence in Jung's comments on synchronicity that resonate with Deleuze's interpretation of repetition and time and which challenge any straightforward foundationalist critique of Jung's thought. A contention of the paper is that Jung and Deleuze envisage enchanted openings onto relations which are not constrained by the presupposition of a bounded whole, whether at the level of the macrocosm or the microcosm. Openings to these relations entail the potential for experimental transformation beyond sedentary habits of thought which are blocked by a disenchanting 'image of thought' that stands in need of critique. Other examples of enchanted openings in Jung's work are signposted in an effort to counter their marginalisation in some post-Jungian critiques and to signal their potential value from a Deleuzian perspective.
\end{abstract}

\section{KEYWORDS}

'image of thought'; enchantment; sympathy; repetition; transversal; multiplicity; 'time out of joint'; vitalism

\section{Introduction}

In the preface to Gilles Deleuze's (1925-1995) most well-known work Difference and Repetition (1968) and in the opening of his and Félix Guattari's (1930-1992) last major publication What is Philosophy (1991), the question 'what are we doing in philosophy today' is broadly repeated (1968/1994, p. xxi; 1991/1994). Elsewhere Deleuze writes: '[w]e're looking for 'vitality.' Even psychoanalysis needs to address a certain 'vitality' in the patient, which the patient has lost, but which the analyst has lost, too' (2003, p. 142). This 'vitality' refers to a pre-individual, impersonal world of relations, relations which are often hidden and concealed under identities such as subject and object in the actual world. ${ }^{1}$

The contention of this paper is that there are openings in C.G. Jung's (1875-1961) thought to relations of this vital kind which can be critically examined using tools from the philosophy of Deleuze and Guattari. To begin this examination, the example I use in the main section of the paper is extracted from comments by Jung in which he refers to the nature of synchronistic relations as 'transversal'. I consider how this might be 
interpreted from a Deleuzian perspective. I contrast this with historical examples used by Jung in his 'Forerunners of the Idea of Synchronicity' exposition from Synchronicity: An Acausal Connecting Principle (1952, pars. 916-946) in order to demonstrate that a Deleuzian interpretation of synchronistic relations as 'transversal' faces challenges from a historical tradition of correspondence, sympathy and harmony. This tradition constrains relations within foundational concepts of the 'whole'. When these relations are constrained, an undesirable set of logical and ethical implications might be implicitly grounded. In the second section of the paper I try to attenuate these undesirable implications by focusing on Jung's use of the term 'multiplicity' from the monograph (1952, para. 828) and how this resonates with a Deleuzian interpretation of time.

Although it was impossible for Jung to have become acquainted with the thought of Deleuze, Deleuze was influenced by Jung and profoundly so. Evidence of this influence appears in almost all of Deleuze's major publications from the 1960s, including his collaborative efforts with French psychiatrist Guattari in the 1970s and 1980s. Erudite secondary studies by Christian Kerslake $(2004,2007)$ also attest to this influence, extending as it does through the vitalist philosophy of Henri Bergson (1859-1941). Deleuze's frequent appeals to Jung's psychology should not be read as an attempt on his part to address insufficiencies in his own thought. As he and Guattari did with so many 'non-philosophies' (scientific, artistic, psychoanalytic), they built an assemblage across their philosophy and other domains of thought in order to find a new 'vitality' for philosophy. Deleuze was an anti-foundational thinker, but he also refers to himself as a 'vitalist', 2 and a 'metaphysician', highly critical of most branches of phenomenology which had emerged before and during his life-time. In the concluding section of the paper I refer to concepts and openings other than synchronicity in Jung's thought which could be exploited from a Deleuzian perspective. This potentially challenges some of the post-Jungian, phenomenological, anti-foundationalist critiques which appear to have marginalised these concepts in order to resolve an apparent insufficiency in Jung's thought.

There has been little scholarship on the Jung-Deleuze relationship from the perspectives of clinicians and academics in Jungian Studies. One of my broader goals with this contribution is to establish a space for reflection on this relationship, to stimulate positive critical comment, and to affirm the continuing relevance that Jung and Jungian thought has beyond the domain of Analytical Psychology.

\section{Jung, Deleuze and organicism: enchantment, sympathy and 'Other' repetitions}

Small things, which were formerly just banal and self-evident, should now have a real value; they should mean something and have a life of their own. For then one can take care of things properly - value things. One becomes considerate, and if it is a deep realisation, one begins to pay attention to the things that simply happen. One never says, 'this is nothing', but one says, 'this is'. And then one understands what the transversal connection, the synchronistic connection, really is. (Jung, 1930-4, para. 340)

The 'transversal connection' and the 'value' of things that is revealed by 'deep-realisation' and 'attention' can be understood as a kind of repetition, one which bestows value because of the enchanting effect that emerges as something from the macrocosm is repeated in the microcosm. What is it that might be 'enchanting' about the experience 
of a 'deep realisation' of this kind? In answering this question I deploy an understanding of enchantment articulated by Jane Bennett: 'Enchantment as a mood requires a cultivated form of perception, a discerning and meticulous attentiveness to the singular specificity of things' (2001, p. 37; italics added). Attentiveness can be glossed as a form of intuition and for Deleuze it would be Bergson's 'method' of intuition ${ }^{3}$ that would serve a possible model albeit with significant modifications incorporated from his reading of Marcel Proust's (1913-1922) In Search of Lost Time (1913). There is something anti-methodological in this intuition because it is involuntary and Deleuze refers to this as a 'fundamental encounter': 'What is encountered may be Socrates, a temple or a demon. It may be grasped in a range of affective tones: wonder, love, hatred, suffering. In whichever tone, its primary characteristic is that it can only be sensed' (1968/1994, p. 139). The object that precipitates such an encounter is not the most important element; rather it is its 'sense' that forces us to think (cf. Bennett, 2001, p. 53). When sense and its relations are opened up in an encounter and no longer subordinated to a 'subject', possibilities for transformation emerge because the habitual and superficial self is confronted with its own dissolution. This is one of the reasons why so much of Deleuze's philosophy is engaged with the 'sense' that he found liberated in experimental works of art, for example in the figures of Francis Bacon (1909-1992), and the literary productions of James Joyce (1882-1941). ${ }^{4}$

In his 'Forerunners' section from Synchronicity: An Acausal Connecting Principle (1952) Jung refers to a line of Neo-platonic, hermetic and Renaissance thinkers from whom examples of this mode of repetition may be discerned: Marsilio Ficino (1433-1499), Pico della Mirandola (1463-1494), Agrippa von Nettesheim (1486-1535), and Paracelsus (1493-1541). He quotes Aggripa: 'Thus the Elements are not only in these inferior bodies [corporeal world], but also in the Heavens, in Stars, in Divels, in Angels, and lastly in God, the maker and archetype of all things' (para. 930). Historically, explanations of this enchanting mode of repetition have often taken the form of metaphysical speculations concerning a holistic and teleological structure of the universe (Bennett, 2001, p. 38). Jung exclaims that '[s]ynchronicity is a modern differentiation of the obsolete concept of correspondence [Correspondentia], sympathy, and harmony' (ibid., para. 995). Deleuze takes a keen interest in common Neo-Platonic and hermetic themes such as the 'One', 'whole', 'unity' and 'totality', themes which resonate closely with the classical notion of sympathy and an organicist conception of the macrocosm as an 'organism' (see Ramey, 2012). ${ }^{5}$ Nevertheless, he rejects a holistic mode of repetition, one associated with the classical holistic notion of sympathy. Deleuze is a thinker of enchantment, one invested in enchanted 'encounters', kinds of repetition in which 'something in the world forces us to think' (1968/1994, p. 176). ${ }^{6}$ Furthermore, I consider Deleuze to be a 'holistic' thinker but one invested in a model of holistic relations that remains resolutely opposed to macrocosmic and microcosmic models of holistic organicism.

Borrowing again from Jung's 'Forerunners' exposition, we find a paradigmatic example of a classical holistic organicism drawn from the Greek physician Hippocrates (460-370bc):

There is one common flow, one common breathing, all things are in sympathy. The whole organism and each one of its parts are working in conjunction for the same purpose and each of its parts are working in conjunction for the same purpose ... the principle extends to the extremist part, and from the extremist part it returns to the great principle, to the one nature, being and not-being. (1952, para. 924) 
In the following passage from (Proust and Signs 1964/2000), we discern Deleuze's awareness of the same tradition of holistic organicism. In the same passage he hints at another mode (or 'fashion') of repetition:

When a part is valid for itself, when a fragment speaks in itself, when a sign appears, it may be in two very different fashions: either because it permits us to divine the whole from which it is taken, to reconstitute the organism or the statue to which it belongs, and to seek out the other part that belongs to it ... The first fashion is that of the Greeks; it is only in this form that they tolerate "aphorisms." The smallest part must still be a microcosm for them to recognise in it an adherence to the greater whole of a macrocosm. The signs are composed according to analogies and articulations that form a great Organism, as we still find it in the Platonism of the Middle Ages and the Renaissance. They are caught up in an order of the world, a network of significant contents and ideal significations that still testify to a Logos $(1964 / 2000$, p. 113)

Deleuze refers to the kind of repetition that he found problematic as a 'brute' or 'bare' repetition. What he means by this is a repetition of the same (1968/1994, p. 128). When he suggests that something in the world forces us to think, this 'something' is neither an empirical object of recognition, nor a former present in time, nor a mythical present, nor an orginary term. Likewise, time is not the mere measure of movement, a 'periodic or circular time which is that of Physis and is subordinate to the events which occur within it' (1968/1994, p. 110). Borrowing from Hamlet, Deleuze seeks to affirm an alternative time, a 'time out of joint', 'time outside the curve which gave it a god, liberated from its overly simple circular figure, freed from the events which made up its [mimetic] content, its relation to movement overturned; in short, time presenting itself as an empty and pure form' (ibid., p. 88).

If we situate the 'brute', 'bare' repetition and 'circular' figure of time in relation to the examples of classical organicism described earlier then what is challenged is the presumed relation between part and whole, a rejection of the view that 'an enchanting phenomenon be understood as part of a divine creation or as a particular instance of a universal will' (Bennett, 2001, p. 40). The image of a non-teleological enchantment can often be found in Deleuze's criticisms of 'organic totality in which each part pre-determines the whole and in which the whole determines the part' (1964/2000, p. 113). Likewise his criticisms of a dialectic of evolution and lingering belief in 'the myth of existence of fragments that, like pieces of an antique statue, are merely waiting for the last one to be turned up, so that they may all be glued back together to create a unity that is precisely the same as the original unity' (1972/1983, p. 42) seem to affirm a narrative of disenchantment.

Deleuze critically interrogates repetition along with difference in his seminal work Difference and Repetition. The main target of this text is what Deleuze calls the 'traditional image of thought':

By this I mean not only that we think according to a given method, but also that there is a more or less implicit, tacit or presupposed image of thought which determines our goals when we try to think. For example we suppose that thought possesses a good nature, and the thinker a good will (naturally to 'want' the true); we take as a model the process of recognition - in other words, a common sense or employment of all the faculties on the supposed same object; we designate error, nothing by error, as the enemy to be fought; and we suppose that the true concerns solutions - in other words propositions capable of serving as answers. (1968/1994, p. xvi). 
This 'model' of thought renders us incapable of thinking 'difference in itself' (1968/1994, xiv) because it subordinates difference to representation, the four criteria of which are identity, resemblance, opposition and analogy. Under this model repetition, as the representation of that which is to be recognised as the same, fares little better. Deleuze states that 'repetition is not generality' (1968/1994, p. 1) and of the reasons he offers for this it is the following that concerns us here. Generality implies an exchange or substitution of particulars based on resemblance and equivalence. From the perspective of generality, repetition is the re-presentation of a universal in a particular, referring to the equivalence of successive individuations of an original identity. 'Generality, as generality of the particular, stands opposed to repetition as universality of the singular' (1968/ 1994, pp. 1-2).

Arguably the genesis of Deleuze's interest in the whole cannot be divorced from the effects that he and others endured under the extremes of political totalitarianism in France during the Second World War. Post-war continental philosophy is marked by the crises of this war and the shadows cast by the names of Auschwitz and Hiroshima. If Western philosophy has traditionally been associated with the promotion of images of reason then during the first half of the twentieth century the systems of judgement that philosophy and its images employed are found wanting. Gregg Lambert claims that the 'event of crisis could also signal for us that point where contemporary philosophy folds back and takes itself as an object of the most radical operations' (2003, p. 15). Deleuze's philosophy and that of his compatriots Emmanuel Levinas (1906-1995) and Jacques Derrida (1930-2004) are exemplary of this moment of auto-critique. Deleuze refers to the 'image of reason' as 'the image of thought,' (see above) and he takes questions of 'difference', 'identity' and 'representation' to be singularly important in the fight against this one-sided Western 'image'; an image that has occluded the singular, and obscured and concealed relations and their geneses within a mode of repetition which subsumes particulars under a universal. In another way, Deleuze's criticism of the 'image of thought' can be read as a disenchantment narrative, for which, however, his practical philosophy paradoxically offers some means of resistance by opening up spaces for enchanted encounters. What is unusual about Deleuze's philosophy is the extent to which he engages with other 'non-philosophies' (Lambert, 2003) such as science, modern art (e.g. Bacon), literature (e.g. Proust, Joyce, Kafka, Beckett), and modern cinema in his attempts to construct a 'thought without image, even at the cost of the greatest destructions and the greatest demoralisations' (1968/1994, p. 132). When philosophy works with these other non-philosophies, together they become a 'machinic assemblage',' capable of producing concepts. This process of production is both critical and creative. It is critical of images of thought which take representation, identity and recognition to be metaphysically foundational. In other words it is critical of images such as the Cartesian Cogito and the Kantian transcendental subject whose function is to ensure that possible experience is immanent to the subject, a subject which stands external and over against a world of objects. This has a disenchanting effect because it conceals the genesis of relations and their syntheses within an image which, says Deleuze, is 'traced from the empirical figures which it makes possible' (1968/1994, p. 151). The creative process involves non-philosophies in an effort to reveal relations and their syntheses when they are liberated from an external, synthesising power. An enchanted 'encounter' is an example of this liberation, an opening, one which often 
takes place 'under the impulse of a shock [rather] than in the excitement of a taste for thinking' (Deleuze, 1968/1994, p. 132). We need to bear in mind that these encounters do not reveal something which is retrospectively determined as having been lost, thereby gesturing to the restoration of a 'natural' way of relating. Rather 'enchantment' concerns a rich source of possibilities and openings for experimental transformations, beyond the subject and beyond the 'human'.

If, as I have claimed, Deleuze is a thinker of enchantment then what alternatives does he propose to the 'brute' and 'bare' model of repetition that he associates with organicism; an organicism that Jung appears to have tacitly endorsed given his selections in the 'Forerunners' exposition. In order to answer this, I return to Jung's final sentence from the opening passage: 'And then one understands what the transversal connection, the synchronistic connection, really is.' Although it is not possible to get a precise purchase on the term 'transversal' as it appears in the work of Deleuze and Guattari, what they mean by it is a kind of communication. In the following passage they refer to this kind of communication in terms of relations:

Between things does not designate a localisable relation going from one thing to the other and back again, but a perpendicular direction, a transversal movement that sweeps one and the other away, a stream without beginning or end that undermines its banks and picks up speed in the middle. (1980/1987, p. 25 ; italics original)

A kind of sympathy can be discerned in the way in which Deleuze characterises transversal communication and transversal relations as occurring 'between' and without beginning or end. Indeed, he and Guattari use the term 'plateau' in the title of their 1980 work $A$ Thousand Plateaus (1980) 'to designate something very special: a continuous, self-vibrating region of intensities whose development avoids any orientation toward a culmination point or external end' (1980/1987, p. 1-2). They explicitly acknowledge the holistic thinker Gregory Bateson (1904-1980) ${ }^{8}$ as their source for this term adding that '[i]t is a regrettable characteristic of the Western mind to relate expressions and actions to exterior or transcendent ends, instead of evaluating them on a plane of consistency on the basis of their intrinsic value' (1968/1994, p. 2). Deleuze employs the term 'multiplicity' to express his contention that 'what counts are not the terms or the elements, but what there is 'between,' - the between are a set of relations that are inseparable from each other. Every multiplicity grows from the middle, like the blade of grass or the rhizome' (Deleuze and Parnet, 1977/1987, p. viii). Plateau, multiplicity, becoming, rhizome and assemblage, are just some of the terms that Deleuze and Guattari will use to convey the priority of the 'between' that characterises transversal relations. They use these concepts creatively, to force their readers to think critically about relations whilst providing in each 'plateau' (of their $A$ Thousand Plateaus) examples of 'unnatural participations or nuptials [which] are the true Nature spanning the kingdoms of nature (1980/1987, p. 241), the products of transversal communication: 'becoming-animal, 'becomingwhale', becoming-dog, becoming-woman', 'becoming-molecular', 'becoming-child' etc. 9

The 'between' of transversal relations can be read as one of Deleuze's critical responses to systems and models of the whole which implicitly or explicitly privilege relations of interiority. Relations of this kind are evident in the mode of repetition characteristic of holistic organicism, i.e. a 'brute' or 'bare repetition' in which relations are determined in advance or 'given' because the 'whole' is given. In other words the whole is 'closed'. In 
Bergsonism (1966), Deleuze claims that we should 'be delighted that the Whole is not given' (1966/1991, p. 104) and that we deceive ourselves in thinking that the whole is 'given' when we confuse space and time by assimilating the latter into the former. He goes to say that, '[o]n the one hand, it is right to compare the living being to the whole of the universe, but it is wrong to interpret this comparison as if it expressed two closed totalities (macrocosm and microcosm)' (1968/1994, p. 105). His concern is that if we prioritise relations of interiority and assume a whole to be closed, then relations are subordinated and any dynamic potential to connect, morph and 'become' in new experimental ways might be compromised.

Relations of exteriority - transversal relations - involve a mode of repetition that Deleuze refers to as an "other' repetition' (1968/1994, p. 25). He says that a 'bare, material repetition (repetition of the Same) appears only in the sense that another repetition is disguised within it, constituting it and constituting itself in disguising itself' (1968/1994, p. 21; italics added). This 'other' repetition 'forms the essence of that in which every repetition consists: difference without a concept, non-mediated difference' (1968/1994, p. 25). Situating this in the context of 'enchantment', Bennett refers to this 'other' repetition as a 'spiral repetition' in which 'things repeat but with a twist. And this twist - or to use the Lucretian term, swerve - makes possible new formations' (2001, p. 39). Where earlier I spoke of 'unnatural participations' and 'becomings', in 'spiral' repetition 'each turn of the spiral enters into a new and distinctive assemblage - with absolutely local chirps, odours, herbs, thoughts, whris images, breezes, light waves, viruses, animals, machines, and minerals in its milieu' (1968/1994, p. 40).

What is not contended in this paper is that Jung's singular use of the term 'transversal' (which occurs in the same sentence as 'synchronistic connection') maps perfectly onto the way in which the term 'transversal' was used by Deleuze and Guattari as a shorthand for relations of exteriority. To the contrary, the examples he employs in his 'Forerunners' section seem to suggest that Jung tacitly affirmed relations of interiority and a version of holistic organicism in his 'modern differentiation' (1952, para. 995) of the classical notion of sympathy. By paying attention to some of the more recent figures that Jung includes in his list of 'Forerunners', e.g. Gottfried Wilhelm von Leibniz (1646-1716) and the late nineteenth century embryologist and neo-vitalist Hans Driesch (1867-1941), the same form of organicism, sympathy and internal relations can be identified. I will pursue some of these identifications in the following section, deploying critical responses from both Deleuze and Jung to Leibniz's notion of a 'pre-established harmony'. These responses indicate that it would be irresponsible to conclude that Jung's account of the 'whole' is isomorphic with the form of organicism deployed in the accounts from the 'Forerunners'.

\section{Time in crisis: time 'out of joint': time and multiplicity}

I have used examples from Jung's 'Forerunners' exposition selectively, and for the purposes of illustrating some of the potential differences between a Deleuzian account of sympathy and enchantment, and Jung's account. It may be the case that the 'transversal connection, the synchronistic connection, really is' similar to an 'other' repetition with 'spiral' dynamics. If this were so an explanation of a 'transversal', 'synchronistic connection' might be complemented by a Deleuzian account of enchanted repetition. 
At the same time this might depend on how strongly we take Jung's claim that synchronicity is 'not based on philosophical assumptions but on empirical experience' (1952, para. 995). Earlier I mentioned Deleuze's interest in what he called a 'fundamental encounter' and how this prompted an intuitive engagement with 'sense' via enchanted, 'other' repetition. Is there something similar in this encounter and the kind of 'empirical experience' that Jung classes as a synchronistic? The 'empirical' material of synchronistic experiences bear little resemblance to the 'empirical' of sensible givens received in passive intuition that would have occupied 'empiricists' such as John Locke (1632-1704) and David Hume (1711-1776). It is also nothing like the object-recognition of possible experience for which Immanuel Kant (1724-1804) transcendentally deduced the a priori intuitions (space and time) and categories of the Understanding as necessary conditions (conditions which remain external to that which they condition). There is something special about synchronistic experiences to the extent that they cannot be traced from what ordinarily passes for the empirical. On the basis of these special experiences we cannot determine the ground of experience as a 'subject'. Indeed, these experiences can be read as challenging such a philosophical assumption, potentially turning synchronicity into a mode of critique.

In order to unpack this further I return to Deleuze's phrase from Hamlet that 'time is out of joint'. He also recounts this phrase in the preface to the English edition of Cinema 2: The Time-Image:

Over several centuries, from the Greeks to Kant, a revolution took place in philosophy: the subordination of time to movement was reversed, time ceases to be the measurement of normal movement, it increasingly appears for itself and creates paradoxical movements. Time is out of joint: Hamlet's words signify that time is no longer subordinated to movement, but rather movement to time. $(1985 / 1989$, p. xi)

An 'image' of time is being challenged according to Deleuze. In Western philosophy the historical moment when this challenge occurs begins with Kant's critical philosophy. Deleuze takes inspiration from the Kantian notion of time as a pure and empty form, a form of interiority. Deleuze writes that 'we should be concerned with a precise moment within Kantianism, a furtive and explosive moment which is not even continued by Kant much less by post-Kantianism' (1968/1994, p. 58). Deleuze uses the formula 'time is out of joint' to summarise this challenge but he also uses the phrase 'I is an Other' (1968/1994, p. 86). In questioning the relationship between time and movement, he is questioning what he considers to be an historical account of the relationship between time, movement and repetition that had been assumed to determine the ground of subjectivity. Deleuze exploits a 'moment' in Kant's thought in order to demonstrate that something fundamental changes. ' $[T]$ he cosmological harmony between the world and the heavens, man and the heavenly Gods, has somehow broken down' (Voss, 2013, p. 125). How? Kant no longer defines time as a cosmological or psychological time. In the 'Paradox of Inner Sense' from his first Critique (1781) he claims that I must experience everything passively under the form of time as the form of interiority. Hence my empirical self is known only as an object of thought, as it appears to itself as a representation. This precludes me from encountering the transcendental subject - an Other - whose spontaneity cannot be appropriated. The important point to note is that my empirical self only has an identity under the form of time. Its identity is no longer guaranteed by something 
that subordinates time to the measure of something other than itself or to something outside it.

In synchronistic experiences, the conclusion can be drawn that a 'normal' image of time is placed in crisis. Roderick Main writes that '[s]ynchronicity flagrantly transgresses the normal ways in which time is understood to operate' and that 'in synchronicity, uniformly unfolding clock time is interrupted with moments of extraordinary timeliness, which in turn can open our eyes to a sense of present time as qualitative, filled with varying landscapes of meaning' (2004, pp. 182-183). Is there a link between a 'time out of joint' and the time of synchronicity that tells us something about the (passive) genesis of the subject?

This is not an easy question to answer. Nonetheless I think the possibility is left open by Jung in the conclusion to Synchronicity: An Acausal Connecting Principle when he takes issue with thinkers such as Leibniz for postulating, 'an act of God, of some principle standing outside empirical nature' (1952, para. 948; italics added) that would be necessary for the coordination of soul and body. He continues that '[i]t is not necessary to think of Leibniz's pre-established harmony or anything of that kind, which would be absolute and would manifest itself in a universal correspondence and sympathy' (1952). What I find of value in this passage is Jung's apparent rejection of an external form of conditioning, a guarantor, presupposed as necessary for ensuring the analytic identity of the subject. Earlier in the monograph, where Jung turns his attention to the thought of Schopenhauer (1788-1860), we find additional evidence which reinforces the rejection of an external 'principle':

Schopenhauer believed in the absolute determinism of the natural process and furthermore in a first cause. There is nothing to warrant either assumption. The first cause is a philosophical mythologem which is only credible when it appears in the form of the old paradox ... as unity and multiplicity all at once. (ibid., para. 828)

Here the external principle is associated with a first cause as unity. Interestingly Jung almost immediately follows this passage by suggesting that if multiplicity were exchanged for unity, 'which is just as likely then Schopenhauer's whole explanation collapses, quite apart from the fact... that natural law possesses a merely statistical validity and thus keeps the door open to indeterminism' (ibid.). Whether the 'paradox' Jung refers to as unity = multiplicity can be equated with Deleuze and Guattari's desire to '[a]rrive at the magic formula we all seek - pluralism = monism - via all the dualisms that are the enemy' (1980/1987, pp. 20-21) will have to be explored at another time. The potential connection between Jung and Deleuze that interests me now is time as 'multiplicity' and 'time out of joint'.

Keeping in mind Jung's critical comments on Leibniz and the harmonia praestabilita, the 'image' of time that Leibniz erects reveals the character of a 'teleologist on the defensive' (Bennett, 2001, p. 69). Leibniz was trying to resolve a crisis of time, a crisis engendered by disenchantment, but his solution was classical. The classical function of God (Scientia Dei) is retained by Leibniz and, thus, he 'spatialised time from the point where God could see the whole of time stretched out across divergent (incompossible) universes in order to choose the world that was the 'most ripe' with possibilities' (Lambert, 2003, p. 13). This idea of the spatialisation of time is important because it helps to unpack what Deleuze means by 'time out of joint'. In Bergsonism he writes that: 
The confusion of space and time, the assimilation of time into space, make us think that the whole is given, even if only in principle, even if only in the eyes of God. And this is the mistake that is common to mechanism and finalism [teleology]. The former assumes that everything is determinable in terms of a state; the latter, that everything is determinable in terms of a programme: In any event time is only there now as a screen that hides the eternal from us, or that shows successively what a God or superhuman intelligence would see in a single glance. (1966/1991, p. 104)

Jung's rejection of the 'external principle' entails a rejection of what is referred to above as a 'spatialised time'. It entails a rejection of a power of judgement that is bestowed upon something 'outside' time, e.g. the judgement of God $^{10}$, whose character is believed to be 'ethical', a power to choose the best of all possible worlds. What is repeated is this choice, finding its principle in what Leibniz refers to as 'compossibility'. I am arguing that Jung rejects this kind of 'judgement of God'. Thus he rejects the theological hypothesis of a selecting God (cf. Kerslake, 2007, pp. 152-154). 'Multiplicity' entails the 'death' of this kind of God and the form of a spatialised time. If time as 'multiplicity' is not governed by something external to it, then it unfolds or unrolls to become a pure straight line, no longer subordinated, as in ancient cosmology, to the measurement of the circular movements of the planets or more generally to the movement of physical bodies in space. The identity of the subject guaranteed within this cosmological order begins to break down as the subordination of time to space is overturned. Daniela Voss summarises the implications of this 'modern' conception of time as follows: 'It has become an infinite, straight line, which will cut right through the consciousness of the subject. Its effect ... carries the subject to the border of the liveable and destroys the well-constituted identity of the subject' $(2013$, p. 215).

We have seen that according to Deleuze it was in the critical philosophy of Kant that resources could be found to deduce a pure and empty form of time. But, Deleuze does not follow Kant who he accuses of subsequently subordinating time to an external, active synthetic unity; the transcendental subject. Unlike the Cartesian Cogito, the transcendental subject is not a substantial being but a universal form, a form which is imposed upon a 'passive' sense. This schism or discontinuity in Kant's thought between concepts and intuitions and the sensible and the intelligible, is established in order to ensure that the unity of the subject-identity is maintained (synthetic identity). Because of this the function of time is once again reduced to the maintenance of identity suggesting to Deleuze that its form has not changed significantly from before. Deleuze rejects what he calls historical 'Man-God permutations' of analytic and synthetic identity: 'The oneness and identity of the divine substance are in truth only the guarantees of a unique and identical Self, and God is retained so long as the Self is preserved. Finite synthetic self or divine analytic substance: it amounts to the same thing' (1968/1994, p. 58). Following post-Kantians such as Salomon Maimon (1753-1800), Deleuze seeks after conditions not of possible experience but of 'real' experience. These are genetic conditions no longer constrained by the necessary imposition of a transcendental subject. In the second chapter, 'Repetition for Itself,' from Difference and Repetition, Deleuze refers to these conditions as 'passive syntheses' of time.

My point is that 'multiplicity' and passive syntheses of time might be construed as openings onto an enchanted repetition. The 'empirical' material of synchronistic experiences indicate a rupture with a spatialised image of time as well as breaking with the 
discontinuity between an external, active power which infuses an otherwise, passive, lifeless material. With respect to the latter we are dealing with a discontinuity and it is this which informs most of the post-Jungian anti-foundationalist critiques of Jung's thought.

\section{Concluding remarks: seeds of anti-foundationalism in Jung's thought}

Enchanted moments and encounters with an 'other repetition' gesture to openings on to transversal relations which are no longer presupposed to be immanent to 'mini-transcendences to humanity itself in early modern scepticism and humanism; to the cogito of Descartes; to the transcendental subject of Kant; and to the phenomenological consciousness in Husserl' (Ramey, 2012, p. 20).

To this list perhaps we could add 'psyche' as a 'primary datum' (Colman, 2017, p. 35) and even 'Self' as an external 'One' of monotheism' (Hillman, 1981, pp. 109-137). Robin McCoy Brooks asserts that 'Jung's foundationalism ... perpetuates the myth of the isolated mind' (2011, p. 292). Similarly Lasdon Hinton argues that Jung's privileging of the Unus mundus as a 'foundationalism repeats a primal error of modern thought that can be very destructive in its unforeseen effects' (Hinton, 2011, 377). If these assertions have merit, then Deleuze's critique of external conditioning could be used alongside the more frequent appeals to Martin Heidegger's (1889-1976) phenomenology offered by some post-Jungians as the most adequate solution to the alienating logical and ethical implications of Jung's alleged 'foundationalism'. Crudely speaking, the orientation of these post-Jungians can be characterised as phenomenological, occasionally utilising philosophical critiques by Levinas and Derrida as well as asserting the importance of Heidegger's phenomenology and its relevance for modern bio-phenomenology and neuroscience (additional allies for Analytical Psychology that militate against the insufficiencies in Jung's 'foundationalism'). Suspects from Jung's corpus other than the Unus mundus which enter into the purview of post-Jungian 'anti-foundationalist' re-visioning include synchronicity (e.g. Brooke, 2015, pp. 70-71; Colman, 2015, p. 319), the archetypes (Colman, 2016, p. 49-51), esse in anima (Brooks, 2011, pp. 498-500; Colman, 2017, pp. 34-36) and the psychoid (Brooks, 2011, p. 500; Colman, 2015, p. 320). By marginalising these concepts it is assumed that the 'dualisms tacitly adopted in Jung's foundationalist epistemology' (Brooks, 2011, p. 494) will be attenuated for analytic theory and practice. The ethical implications of foundationalism in clinical practice 'privilege the illusion of the analyst's epistemological authority' (Brooks, 2011, p. 495). ${ }^{11}$ Furthermore, foundationalism undermines 'the task of entering into the world of the other' which 'we aim to do as psychotherapists, with the caveat that, because we are also wanting to influence the other's world, we need to invite them to enter our world' (Colman, 2015, pp. 331-332). In Levinasian terms the 'Face of the Other', including our patients in all their complexity and creativity, may be subsumed to an idea' (Hinton, 2011, p. 376) necessitating the need to 'manifest the Levinasian spirit of ethical relation into the clinical realm ... a surrender to the utter enigma of the patient, recognising that I am always already held hostage to his or her suffering (or any state) ...I must ... assume responsibility for the feeling of what is happening between us' (Brooks, 2013, p. 86). ${ }^{12}$

What these arguments have in common is a critical interrogation of the logical and ethical implications of a certain discourse of relations. In each case what is questioned is the presupposition of an external condition that is larger than what it conditions and 
which determines relations a priori. One might say that post-Jungian anti-foundational critiques sift out and expose an 'image of thought' in the work of Jung that stands in need of correction. The marginalisation of certain concepts (listed above) occurs because each is assumed to reinforce a hierarchical separation between subject/ psyche and object, spirit and matter (inside and outside), analyst and analysand. Although I find many valuable resources in these post-Jungian critiques for demonstrating the continuing relevance of modern continental philosophical thought for Jungian Studies, I am left wondering if their phenomenological analyses of foundationalism go far enough toward offering a genesis of conditions or if they succumb to the resurrection of a 'mini-transcendence' in another form to which relations are immanent. If we take the recent turn to a bio-phenomenological paradigm of embodiment offered by Warren Colman as a potential solution to the alienating and disenchanting effects of Jung's 'Cartesianism', his request that we treat all 'life' as 'bounded in a nutshell' (2015) seems to relocate the borders of an active synthetic 'unity' to the boundaries of the organism. Arguably this has a liberating effect on relations, attenuating any stark separation between 'mind' and 'body', but my concern would be that it reinforces relations of interiority, conceiving of 'life' as autopoietic and in terms of organisationally closed wholes. ${ }^{13}$ I worry that a new foundation, whole, or external condition is being resurrected in order to correct the 'error' of Descartes. Following Claire Colebrook I would categorise this line of thought as a modern example of 'active vitalism':

We can discern this vitalism in three contemporary motifs: an insistent, tireless and bitter antiCartesianism that accuses Descartes of separating thought from embodied life; a joyous 'return' to living systems, autopoietic bodies, embodied brains, affect and the feeling of what happens; and a redemptive departure from the supposedly overly linguistic strictures of 'theory' to a phenomenology of the lived.' (2010, p. 48)

If 'we' have a 'natural' and embodied mode of relating, then why did the thought of Descartes and whole populations succumb to 'error' and conceal this mode of relating with all its disenchanting consequences? A fuller genesis of the 'error' would be required.

From a Deleuzian perspective it can be contended that the concepts which are marginalised in the post-Jungian critiques I referred to above, can be reimagined as 'openings' to enchanted 'Others': repetition as an enchanted 'other'-repetition in the example I presented from synchronicity in this paper; esse in anima as an 'opening' to an enchanted sensation; the 'psychoid' as an 'opening' to an enchanted vitalist-materialism and psychoid-archetypes as openings to enchanted spatio-temporal dynamisms. Each of these examples can be supported with evidence from Jung's own work and from the work of scholars within Jungian studies (Addison, 2009, 2016; Bishop, 2008, 2017), Deleuze Studies (Kerslake, 2004, 2007) and elsewhere (Barentsen, 2015). These are Jung's own concepts, concepts he creates, and this suggests to me that he was engaged with the problem of the boundaries of the psyche all his life, but particularly during his later years, and that he sought to provide his readers with a way to think about the dynamic fluidity of these boundaries. These concepts are 'images' of thought in Jung's work, they are put to work, helping us to move, and think beyond what we experience, challenging us to avoid subordinating psychic life, a life of 'vitality' to the very foundational premises that some accuse their operational purpose of reinforcing. It is with regret that I have not been able to consider these examples in any 
detail in this paper. Nonetheless I have attempted to prepare the groundwork for them all, using the example from synchronicity in the manner of a primer.

\section{Notes}

1. Lambert cautions that the term 'vitality' has led to many mistaken assumptions that Deleuze was addressing a traditional notion of philosophical vitalism (Lebensphilosophie), but Deleuze was referring to something else when he speaks about 'vitality' in relation to the 'uncovering of a world of pre-individual, impersonal singularities' in place of a world occupied by Individuals and Persons' $(2012$, p. 7).

2. In a 1988 interview Deleuze remarked: 'Everything I've written is vitalistic, at least I hope it is' (1995, p. 143).

3. The influence of Bergson's notion of intuition on Jung's use of this term has been examined in the literature. See Gunter, 1982, pp. 635-652; Shamdasani, 2003, pp. 207-210; Kerslake, 2007, pp. 49-100; Pilard, 2015, pp.155-168; Addison, 2016, p. 567-587.

4. An essay which complemented the themes of organicism that this paper seeks to address might situate Jung's complicated relationship with Joyce's Ulysses (1919) in relation to the same theme from an aesthetic perspective. It might also consider in detail possible resonances between Jung's description of himself as an 'empiricist' and Deleuze's philosophical approach which he characterised as 'transcendental empiricism'.

5. It may appear perplexing that a 'recent' continental philosopher like Deleuze, often labelled as a 'post-structuralist' and 'post-modernist' thinker, would take an interest in these themes at all.

6. In various ways the following Deleuzian scholars have demonstrated that Deleuze can be regarded as a thinker of enchantment; Bennett, Kerslake (2007), Colebrook (2010), Brent Adkins and Paul Hinlicky (2013) and Joshua Ramey (2012).

7. This term makes its most frequent appearance in the eleventh 'plateau', '1837: Of the Refrain' of $A$ Thousand Plateaus (1980/1987, pp. 310 - 350).

8. It might be worth recalling that Bateson (1904-1980) was influenced by Jung, particularly his deployment of Pleroma and Creatura from Septum Sermones as Mortuos (Seven Sermons for the Dead) which Jung wrote between 1913 and 1916. For Bateson it is the interface (interaction) between pleroma and creatura that is significant as this enables a system to utilise difference.

9. Most of these 'becomings' are detailed in the tenth plateau of $A$ Thousand Plateaus: '1730: Becoming-Intense, Becoming-Animal, Becoming-Imperceptible' (1987, pp. 232-309).

10. Deleuze and Guattari borrow this phrase from a play by Antonin Artaud (1896-1948), 'To Have done with the Judgement of God,' (1947). They discuss this in the sixth 'plateau' of $A$ Thousand Plateaus 'How do you Make yourself a Body without Organs' (1980/1987, p. 150).

11. I am not entirely convinced by this given Jung's keen awareness that '[p]ersonal and theoretical prejudices are the most serious obstacles in the way of psychological judgement' (1934, para. 237, cf. pars. 318, 319, 342)

12. Deleuze's 'immanent ethics', largely inspired by Spinoza and Nietzsche, is incompatible with Levinas' stress on the absolute transcendence of the Other. Daniel Smith writes that the 'ethical themes one finds in transcendent philosophies like those of Levinas and Derrida an absolute responsibility for the Other that I can never assume, or an infinite call to justice that I can never satisfy - are, from the Deleuzian point of view of immanence, imperatives whose effect is to separate me from my capacity to act. From the viewpoint of immanence, in other words, transcendence, far from being our salvation, represents our slavery and impotence reduced to its lowest point ... for Deleuze transcendence is the fundamental problem of ethics, what prevents ethics from taking place, so to speak' $(2012$, p. 177).

13. Deleuzian critiques of the conception of the 'organism' in the school of 'autopoiesis' developed by the Chilean biologists Humberto Maturana and Francisco Varela are presented in the work of Colebrook (2010, pp. 29-30,49-50, 141-144, 155-157) and Alberto Toscano, (2006 pp. 55-60). 


\section{Disclosure statement}

No potential conflict of interest was reported by the authors.

\section{Funding}

This work was supported by the Arts and Humanities Research Council (AHRC) [grant number AH/ N003853/1].

\section{Notes on contributor}

Christian McMillan, PhD, is Senior Research Officer on a research project titled "One world': logical and ethical implications of holism' funded by the Arts and Humanities Research Council, UK in the Department of Psychosocial and Psychoanalytic Studies at the University of Essex. His forthcoming publications include: 'The 'image of thought' and the State-form in Jung's 'The Undiscovered Self' and Deleuze and Guattari's 'Treatise on Nomadology' in Jung, Deleuze and the Problematic Whole (eds. Roderick Main, David Henderson and Christian McMillan, 2019); 'Kant's influence on Jung's vitalism in the Zofingia Lectures' in Holism: Possibilities and Problems (eds. Christian McMillan, Roderick Main, and David Henderson).

\section{References}

Addison, A. (2009). Jung, vitalism and 'the psychoid': An historical reconstruction. Journal of Analytical Psychology, 54(1), 123-142.

Addison, A. (2016). Jung's psychoid concept and bion's proto-mental concept: A comparison. Journal of Analytical Psychology, 61(5), 567-587.

Adkins, B., \& Hinlicky, P. R. (2013). Rethinking philosophy and theology with deleuze: A new cartography. London: Bloomsbury Publishing.

Barentsen, G. (2015). Silent partnerships: Schelling, jung and the romantic metasubject. Symposium: Canadian Journal of Continental Philosophy, 19(1), 67-79.

Bennett, J. (2001). The enchantment of modern life: Attachments, crossings, and ethics. Princeton: Princeton University Press.

Bishop, P. (2008). The timeliness and the timelessness of the 'archaic': Analytical psychology, 'primordial' thought, synchronicity. Journal of Analytical Psychology, 53(4), 501-523.

Bishop, P. (2017). On the blissful islands with nietzsche and jung. London: Routledge.

Brooke, R. (2015). Jung and phenomenology. London: Routledge.

Brooks, R. M. (2011). Un-thought out metaphysics in analytical psychology: A critique of jung's epistemological basis for psychic reality. Journal of Analytical Psychology, 56, 492-513.

Brooks, R. M. (2013). The ethical dimensions of life and analytic work through a levinasian lens. International Journal for Jungian Studies, 5(1), 81-99.

Colebrook, C. (2010). Deleuze and the meaning of life. London: Continuum Press.

Colman, W. (2015). Bounded in a nutshell and a king of infinite space: The embodied self and its intentional world. Journal of Analytical Psychology, 60(3), 316-335.

Colman, W. (2017). Soul in the world: Symbolic culture as the medium for psyche. Journal of Analytical Psychology, 62(1), 32-49.

Deleuze, G. (1966/1991). Bergsonism (H. Tomlinson \& B. Habberjam, Trans.). London: Zone Books.

Deleuze, G. (1968/1994). Difference and repetition (P. Patton, Trans.). New York: Columbia University Press.

Deleuze, G. (1995). Negotiations, 1972-1990 (M. Joughin, Trans.). New York: Columbia University Press.

Deleuze, G. (1964/2000). Proust and signs (R. Howard, Trans.). Minneapolis, University of Minnesota Press.

Deleuze, G. (2003). Desert islands and other texts (1953-1974). New York: Semiotext(e).

Deleuze, G., \& Guattari, F. (1972/1983). Anti-Oedipus: Capitalism and schizophrenia (R. Hurley, M. Seem \& H. R. Lane, Trans.). Minneapolis: University of Minnesota Press. 
Deleuze, G., \& Guattari, F. (1980/1987). A thousand plateaus: Capitalism and schizophrenia (B. Massumi, Trans.). Minneapolis: University of Minnesota Press.

Deleuze, G., \& Guattari, F. (1991/1994). What is philosophy? (H. Tomlinson \& G. Burchell, Trans.). New York: Columbia University Press.

Deleuze, G., \& Parnet, C. (1977/1987). Dialogues (H. Tomlinson \& B. Habberjam, Trans.). New York: Columbia University Press.

Gunter, P. A. Y. (1982). Bergson and jung. Journal of the History of Ideas, 43(4), 635-652.

Hillman, J. (1981). Psychology: Monotheistic or polytheistic. In L. M. David (Ed.), The New polytheism (pp. 109-137). Dallas, TX: Spring Publications.

Hinton, L. (2011). Transcendent truth or comforting fiction? Journal of Analytical Psychology, 56, 375396.

Jung, C. G. (1930-4). Visions: Notes of the seminar given in 1930-1934 by C.G. Jung, ed. C. Douglass, 2 vols. London: Routledge. 1998.

Jung, C. G. (1934). The practical use of dream analysis. In Collected works, 16 vols the practice of psychotherapy, (2nd ed.). London: Routledge. 1966

Jung, C.G. (1952). Synchronicity: An acausal connecting principle. In Collected works, 8 vols the structure and dynamics of the psyche. (2nd ed.). London: Routledge. 1969.

Kerslake, C. (2004). Rebirth through incest. Angelaki, 9(1), 135-157.

Kerslake, C. (2007). Deleuze and the unconscious. London: Continuum Press.

Lambert, G. (2003). The non-philosophy of gilles deleuze. London: Continuum Press.

Lambert, G. (2012). In search of a new image of thought: Gilles Deleuze and philosophical expressionism. Minneapolis: University of Minnesota Press.

Main, R. (2004). The rupture of time: Synchronicity and Jung's critique of modern Western culture. Hove: Brunner Routledge.

Pilard, N. (2015). Jung and intuition. London: Karnac.

Ramey, J. (2012). The Hermetic Deleuze: Philosophy and the spiritual ideal. Durham: Duke University Press.

Shamdasani, S. (2003). Jung and the making of modern psychology: The dream of a science. Cambridge: Cambridge University Press.

Smith, D. (2012). Essays on deleuze. Edinburgh: Edinburgh University Press.

Toscano, A. (2006). The theatre of production: Philosophy and individuation between Kant and Deleuze. Basingstoke: Palgrave Macmillan.

Voss, D. (2013). Conditions of thought: Deleuze and transcedental ideas. Edinburgh: Edinburgh University Press. 